Improving professional service operations: action research in a law firm

\begin{tabular}{|r|l|}
\hline Journal: & International Journal of Operations and Production Management \\
\hline Manuscript ID & IJOPM-10-2020-0696.R2 \\
\hline Manuscript Type: & Research Paper \\
\hline Keywords: & $\begin{array}{l}\text { Professional Service Firms, Soft Systems Methodology, Action Research, } \\
\text { Change Management, Legal Service, Professional Service Operations } \\
\text { Management }\end{array}$ \\
\hline \multicolumn{2}{|l}{} \\
\hline
\end{tabular}




\title{
Improving professional service operations: action research in a law firm
}

\author{
Structured Abstract \\ Purpose \\ The purpose of this paper is to demonstrate how action research-based interventions can effect \\ change in a complex challenging professional service environment (Lewis and Brown, 2012). \\ This paper presents a successful way to do this. Firstly, by eliciting factors for change driven \\ by deregulation in the UK's legal service sector (Falconer, 2005). Secondly, by designing and \\ implementing context-sensitive change in a selected legal service firm.
}

\section{Design/methodology/approach}

This research adopts a Participatory Action Research methodology involving the use of systems thinking (namely the PrOH Modelling Methodology) to design suitable interventions and catalyse change.

\section{Findings}

This study has generated new knowledge on three fronts - to the legal service operations, to methodology, and to the intellectual framework used for abductive reasoning (Checkland and Poulter, 2006). Lessons are transferable to wider professional service operations research. Findings indicate, despite traditional challenges of delivering typical professional services, 
there is potential for rationalising processes and service delivery commodification. Mainly in the low volume, high variety legal service typology (Silvestro et al., 1992).

\section{Research limitations/implications}

This research uses data from an in-depth study of a single organisation.

\section{Practical implications}

This research helped legal service professionals to improve overall efficiency and effectiveness and create new management tools.

\section{Social implications}

This research could help improve legal service operations and make them more accessible.

\section{Originality/value}

This research applies a novel, systems thinking based methodology for the first time in a complex professional service operations environment leading to three-fold contributions in the areas of practice, theory and methodology. The paper uses a change management framework (the Change Kaleidoscope), a soft systems methodology (PrOH Modelling) and applies these to legal services.

Keywords: Professional Service Firms, Soft Systems Methodology, Action Research, Change Management, Professional Service Operations Management, Legal Service. 


\section{Introduction}

The professional services sector accounts for a significant portion of economy and employment in developed economies and is one of the fastest growing sectors. Professional services such as law, accounting, medicine, management consulting, investment banking, advertising, engineering, architecture etc., are good examples of an increasingly professional service and knowledge-based economy.

Legal services are considered a classic example of professional services (Nordenflycht, 2010) but are criticised for their need to be more efficient, effective and economical in an increasingly competitive UK legal market (Falconer, 2005). Studies indicate that little research has gone into development and application of operations management (OM) theory in professional service contexts, and especially in law firms (Lewis and Brown, 2012; Sampson, 2012; Kaiser and Ringlstetter, 2011; Machuca et al., 2007). Although substantial literature on law firms has focused on change and transformation it tends to be at a strategic and institutional level (Cooper et al., 1996; Sherer and Lee, 2002; Pinnington and Morris, 2003) with few empirical studies on management practices and challenges at an operational level in law firms.

The new Legal Services Act (2007), sometimes dubbed 'Tesco Law', intends to make buying legal services as easy as buying a tin of beans; and has made the sector vulnerable to threat of new entrants and has created radical market dynamics. According to a 2018 survey $40 \%$ of Top $10,27 \%$ of Top $11-25$ and $46 \%$ of Top $26-50$ law firms in the UK considered the possibility of a merger for reasons of growth and survival (PwC, 2018). A substantial level of consolidation across the sector and increased price competition has led to many firms making alternative fee arrangements to stay in business. 
Previous studies help to explain how endogenous and exogenous forces compel professional service firms to change or innovate (Sherer and Lee, 2002); this paper builds on these forces and explores the operations management challenges of a particular law firm. This study directly engages with professionals and managers through action research that elicits endogenous and exogenous drivers for change - and reveals how the firm adapted - becoming more productive and efficient with an increased ability to deliver higher-valued services to clients and compete with the new entrants.

\section{Literature precis - managing professional service operations}

Literature considers professional services, such as legal service, to be a relatively pure form of service consisting of extensive customer contact, process customization, complexity and throughput variability (Schmenner, 1986; Goodale, et al., 2008). As such two values common in the manufacturing sector - productivity and efficiency - are becoming prevalent in legal services delivery but can jar with the ethos of more traditional professionals (Freidson, 2001). Early social theorists predicted that professionals would struggle with production-orientated values, and operate efficiently in large firms, due to the inherent conflict between individualist orientations of professionals and pressure to conform in organizational hierarchies (Blau and Scott, 1962). Also because conflicting behaviours such as the 'producer-manager' dilemma (Lorsch and Mathias, 1987) and the 'wildcat herding' phenomenon (Lowendahl, 1997) become increasingly observable.

Nordenflycht (2010) proposed a taxonomy of professional services which indicates that legal service delivery has the highest degree of professional service intensity compared to other 
professional services and is characterised by a set of three distinct features that include knowledge intensity, low capital intensity and professionalised workforce. Although these represent various operations management challenges there is little research to reveal the causes and remedies of such issues, particularly within legal services (Harvey et al., 2016).

Owing to challenges in governing complex partnerships, many firms have resorted to increasingly corporate-style operations that use more formal structures and administrative systems for financial control, human resource development and knowledge management (Empson and Chapman, 2006). For instance, previous studies on law firms indicate that the traditional 'professional partnership' (sometimes referred to as 'P2 archetype') is slowly being replaced by more 'business-like' organisations known as 'managed professional business' (sometimes referred to as a 'MPB archetype') (Cooper, Hinings, Greenwood and Brown, 1996; Pinnington and Morris, 2003). This phenomenon has become more prominent in recent years as incumbent law firms risk losing the price battle to new 'supermarket law shops' which are more proficient at delivering 'mass services' than traditional law firms; the new 'supermarkets law shops' are considered by traditionalists as the antithesis of 'professional services' in Schmenner's (1986) service process matrix.

The recent growing body of work on how to organise high volume, low variety operations akin to service factories (Schmenner, 1986, 2004; Lewis and Brown, 2012; Giannakis et al., 2018; Sampson, 2020) is useful to address the above challenges. For instance, Harvey et al., (2016) report on the existence of significant amounts of standard work within professional service operations - stimulating the deployment of process analytics and improvement interventions. Even so, very few studies have focused on legal service operations; notable exceptions are Clegg et al., (2020), Giannakis et al., (2018), Lewis and Brown (2012), Jaakkola (2011), and Goodale et al., (2008). 
Most recently, Sampson (2020) presents a model of service automation and a framework for reconfiguring tasks in professional service systems. There is still however not enough research on improving legal service operations and implementing change at an organisation level, and there is little empirical evidence on how and to what extent different legal services could be redesigned to better deliver efficiencies as well as increase value to clients. Ertel and Gordon (2012, p.132) poignantly question, "How far can legal services be mapped out, specific activities delineated and sequenced, and the work distributed among providers?"

New research below addresses these literary concerns.

\section{The organisational setting: Solicitors Co.}

Solicitors Co. (SC) is a law firm that has operated for over 140 years, based in the Midlands, UK, employing over 250 staff. SC is considered to be a full-service law firm providing a variety of legal services grouped into nine departments; namely, Personal Injury, Dispute Resolution, Commercial Property, Residential Property, Family, Corporate and Commercial, Employment, Private Client, and Private Criminal.

This action research project made intervention into five different service lines (Road Traffic Accident, Wills and Probate, Dispute Resolution, General Litigation, Corporate Services and Commercial Property). In depth discussions in this paper focus on Dispute Resolution. Further general findings and discussion draws on action research across all five service lines.

\section{Methodology: improving operations using action research}


This study used Participatory Action Research (PAR) and systems thinking. The principles of systems thinking have been widely applied to solve complex real-life problems in management, and to facilitate organisational change (Ackoff, 2006; Jackson, 2006). Within systems thinking a novel methodology is used, known as the Process Oriented Holonic (PrOH) Modelling (Clegg, 2007), which was developed from the principles of soft systems methodology (SSM) (Checkland, 1981) and the SSM learning cycle (Checkland and Poulter, 2006, p.11). The use of PrOH Modelling articulated and facilitated the analysis of legal service processes and engaged people in a structured debate about desirable and feasible change.

Figure 1 shows three phases of this action research: the legal service operations 'problem situation' (endogenous and exogenous forces), 'intervention' (using the 'Product-Process Matrix', the 'Change Kaleidoscope' and 'PrOH Modelling'), and 'learning from intervention' ('S' - Situation, 'M' - Methodology and 'T' - Theoretical / Intellectual Framework').

\section{Action Research Framework}

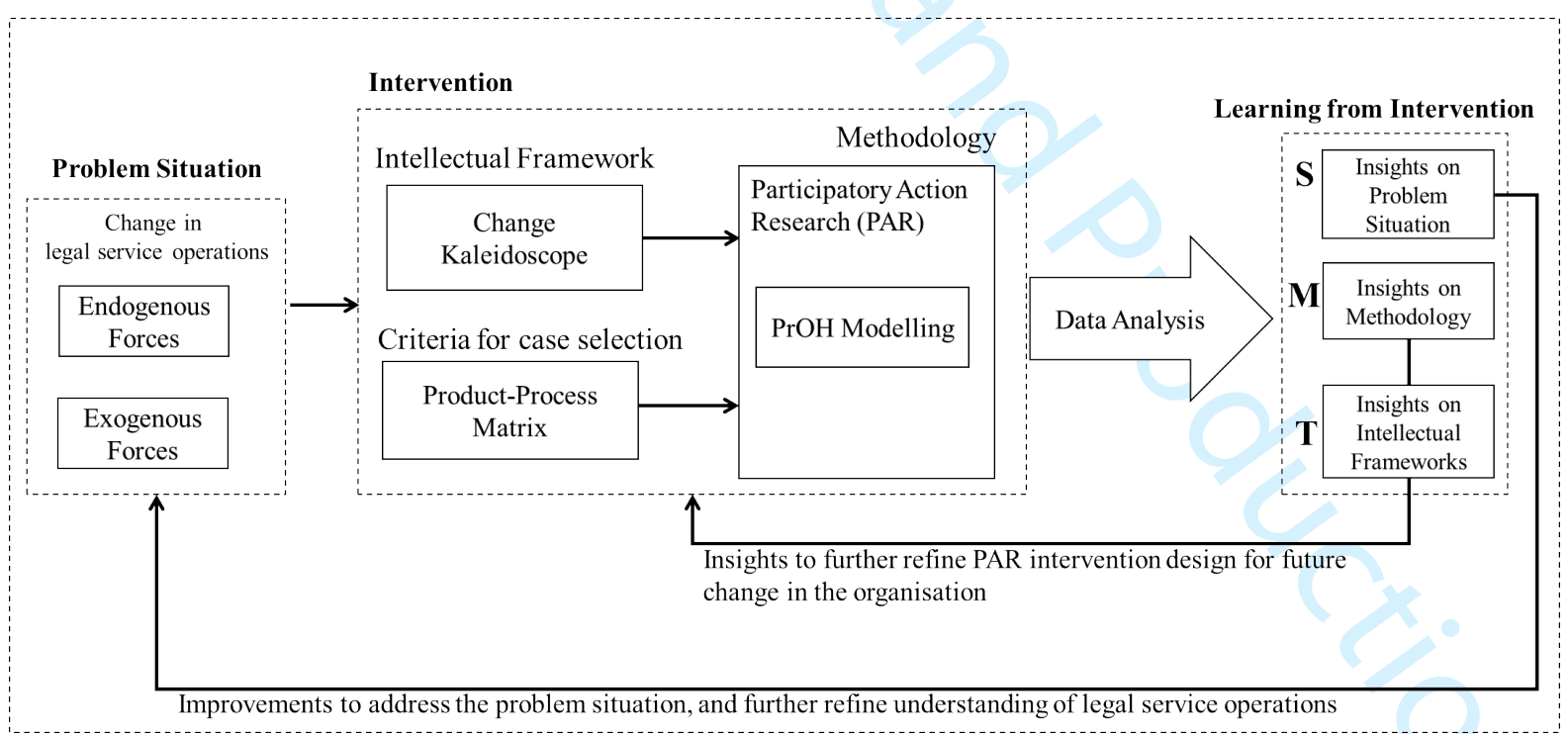

Figure 1: Action research adapted from Checkland (1981) 
According to Checkland, action research should ultimately generate learning from intervention about (a) the problem situation or area of application ' $\mathrm{S}$ ' - in this example managing legal service operations (b) the ideas in the theoretical or intellectual framework ' $\mathrm{T}$ ' used in action research - in this example the Change Kaleidoscope and (c) the methodology or approach ' $\mathrm{M}$ ' used to improve the problem situation - in this example Participatory Action Research and PrOH Modelling.

A detailed description of the methodology, phase by phase, is in the following sections.

\section{Problem situation: articulation of endogenous and exogenous forces at an operational level}

Data was gathered at the beginning of the action research project from five focus groups, conducted with 21 staff in different roles and from different departments in SC, this is given in Table 1. Participants were from all organizational levels, from secretary to senior partner. Participants gave their opinions on their day-to-day organizational challenges. Focus groups generated 80,000 words of rich data (recorded and transcribed) from eight hours of recording. Data from the focus groups was, by text coding and abstraction, formed into 'endogenous themes' and 'exogenous forces' given in Table 1.

Table 1: Endogenous and exogenous factors driving change in SC.

\begin{tabular}{|l|l|l|}
\hline & & \multicolumn{1}{|c|}{ Empirical themes and Illustrative data } \\
\hline Endogenous & $\begin{array}{l}\text { Theme 1: Need } \\
\text { for improving } \\
\text { operational } \\
\text { efficiency }\end{array}$ & $\begin{array}{l}\text { Operational efficiency in process-driven work } \\
\text { "A major issue we're looking at is becoming more efficient in the way in } \\
\text { which we deal with high volume and process driven work, with reference } \\
\text { to precedents and procedures and everything else that we can think of in } \\
\text { that way which will overall make us competitive in the marketplace } \\
\text { because it's not just all about fees. It's about the fact that we have good } \\
\text { knowledge in the area and a lot of experience. So, it's just balancing it all } \\
\text { up". (Associate) }\end{array}$ \\
\hline
\end{tabular}




\section{Theme 2: Need $\quad$ Innovation in pricing driven by competition}

for innovative

practices in

pricing and service delivery

\section{Minimising operational costs}

"We're not the High Street practice anymore, we're not exclusively a commercial firm either, but our costs are increasing. There was only a fairly minor increase this year but, nevertheless, they are rising". (Partner)

"I think we're going to have to think very seriously about how we charge. We're going to have to start thinking about fixed fees, which is very difficult with what we do, where to pitch it. It isn't simply a case of saying I'll charge you X pounds for this deal. It's got to be more creative than that. But it certainly needs a lot of thinking. To make it worthwhile for us but attractive to the clients and to keep a hold of how it's working. But it's got to be done because other people are offering it". (Partner)

\section{Innovation in pricing to deviate from routine models}

"Not necessarily a fixed fee. Any innovation that makes you more attractive ... is the way forward. I think, you know, it can be done for most areas of law, but I think for individual clients, fixed fee is not always the best way or what they want for certain clients". (Associate)

\section{Innovation in all the aspects of service delivery}

"You know for people that have been here 15, 20 years and for it to have been a traditional law firm we might've spoken about 'innovation' but were we innovative? No. Now we know why we are changing”. (Partner)

\section{Self-service and advanced features for clients}

"A web-based case management system for clients, it's giving them an opportunity to manage their affairs better. If they want to print it off then that's up to them, let them do that and keep their paper files. I'm not saying that every client would want it but you give them an option". (Partner)

Theme 3: Need
for innovative
people
management and
performance
measurement systems

\section{Measuring individual performance}

"We get pressures from finance and from the partners to get our recovery rates right. And there might be a job that I think, I can't quote that much; it's only a small job. You know, I quote $\mathrm{X}$ times, I've got three times on the clock and, you know, it's not worth more than X for that client. But if I bill it for X, I'm only 30\% effective". (Associate)

\section{Effectively balancing chargeable and non-chargeable time}

"I spent 8 hours doing non-chargeable stuff yesterday, all entirely necessary but 8 hours. You know sometimes you don't have any time to do any work or look after clients because you're doing so much other stuff'. (Partner)

\section{Theme 4: Need} for a cultural shift towards greater inclusivity across roles and departments

\section{Internal divide - Fee earner vs Fee burner}

"Everybody has a part to play, fee earners are genuinely valued more in law firms than other people are because it's the fees that pay for everything and make it successful in financial terms and you've somehow got to make people who are not fee earners valued as much and that's a massive change for any law firm because traditionally that's how they operate". (Partner)

“... support staff don't have the same buy-in to what the firm is about, but that's probably because we haven't been brilliant at communicating that to them". (Partner) 


\begin{tabular}{|c|c|c|}
\hline & & $\begin{array}{l}\text { "There is a big cultural shift that needs to be made. We need to get rid of } \\
\text { the, them and us". (Partner) } \\
\text { "I don't think you can generalise but I think that the lawyers tend to be } \\
\text { more switched on in terms of the big picture and they have a stake in the } \\
\text { company and what it's about and I'm not saying that the support staff } \\
\text { don't, but probably not to the same degree". (Partner) }\end{array}$ \\
\hline & $\begin{array}{l}\text { Theme 5: Need } \\
\text { for developing } \\
\text { skills and } \\
\text { capabilities in } \\
\text { engaging wider } \\
\text { groups }\end{array}$ & $\begin{array}{l}\text { Effectively communicating firm's strategy to staff } \\
\text { "We need to know what we are supposed to be aiming for and achieving. } \\
\text { And unless you have a meeting with your Head of Department and it's } \\
\text { explained what's expected of you, it's difficult to know". (Solicitor) } \\
\text { Engaging people in wider initiatives } \\
\text { "I don't think we've been particularly good at bringing people out of } \\
\text { themselves in terms of contributing to the bigger picture, so that they feel } \\
\text { part of it as opposed to something that is just happening to them. They } \\
\text { don't take ownership of it because they've not been given any ownership } \\
\text { of it". (Partner) } \\
\text { "Perhaps it's about imparting the enthusiasm to those that aren't and trying } \\
\text { to get us to understand the importance of wider changes in the industry". } \\
\text { (Associate) }\end{array}$ \\
\hline \multirow[t]{2}{*}{ Exogenous } & $\begin{array}{l}\text { Force 1: } \\
\text { Regulatory } \\
\text { requirements on } \\
\text { legal costs }\end{array}$ & $\begin{array}{l}\text { Transparency and proportionality of costs } \\
\text { "Years ago, people used to say, "Well, this is our hourly rate," and that } \\
\text { was the extent of the information they were given about costs at the } \\
\text { beginning. Now we have to give an estimate, which is almost treated as a } \\
\text { fixed fee agreement. Clients assume that that's what it's going to be and it's } \\
\text { very difficult". (Partner) }\end{array}$ \\
\hline & $\begin{array}{l}\text { Force 2: 'Tesco } \\
\text { Law’ (Legal } \\
\text { Services Act } \\
\text { 2007) }\end{array}$ & $\begin{array}{l}\text { Competitive pressure for fixed fee } \\
\text { "I think what we're concerned with in our department at the moment is } \\
\text { making sure that we can offer work on a fixed fee basis because of 'Tesco } \\
\text { Law' and that we've got to maintain a good relationship with our clients so } \\
\text { that they don't go elsewhere for a cheaper service". (Partner) }\end{array}$ \\
\hline
\end{tabular}

Table 1 lists endogenous themes and exogenous forces acting on SC that, although not exhaustive, are likely to be representative of wider UK legal services because lawyers draw on a common regulated body of knowledge and standards (Law Society of England and Wales). Therefore, these themes and forces are also likely to affect other similar law firms. Accomplishing change is inherently difficult because SC, like other law firms, is also largely dependent on informal systems (cultural or operational). Attuning to these systems, which guide people's behaviour, is time consuming, tacit and stochastic. It was therefore necessary 
to engage fully in the complex systemic nature of change at SC before attempting any new operational or strategic implementations.

\section{Intervention: three main research tools}

Demographic, economic, social and political forces often drive organisational change. According to March (1981, p.563), 'although organisational response to environmental events is broadly adaptive and mostly routine, the responses take place in a confusing world'. Strategic change intervention is therefore one of the most important undertakings of an organisation (Sonenshein, 2010). Research suggests more than $70 \%$ of the change interventions fail and even the largest and most successful organisations have suffered from uncertainty and bad luck (Nohria and Beer, 2000).

\subsection{Selecting service lines for intervention - volume and variety matrix}

SC's nine different legal services use a heterogeneous mix of volume and variety in their operations. These services were typified using the 'product-process matrix' proposed by Hayes and Wheelwright (1979a, 1979b), with Silvestro et al's' (1992) adaptations for services, Five representative legal services were selected for this project. These five services were: low volume and high variety services (Dispute Resolution, and Corporate Services), high volume and low variety services (Road Traffic Accident Claims, and Wills \& Estate Planning), and a medium volume and medium variety service (Commercial Property Services).

\subsection{Appraising the nature of change required - the Change Kaleidoscope}


The intervention phase used Balogun and Hope-Hailey's (2008) Change Kaleidoscope as the intellectual framework ' $T$ ' in which learning was to be defined using abductive rationalisation. Use of a theoretical framework was practised and endorsed by Checkland (1981) as he stated that, "there must be an intellectual framework, declared in advance, without which, action research can quickly become indistinguishable from mere action". A theoretical framework is often sufficient for PAR if it can provide reasonable explanations of behaviours. In contrast a full academic theory is not always necessary and may even lead to accusations by those in the systems under observation as being esoteric, irrelevant and unhelpful for explaining observed behaviours.

Research indicates that there is no standard formula for change interventions, and organisation context-sensitive choices become critical in designing change (Balogun and Hope Hailey, 2008). Hence, the Change Kaleidoscope became the intellectual framework because of its practical and useful emphasis on temporal context-sensitive features of change. The Change Kaleidoscope focuses on eight practical 'context-sensitive features' of an organisation that relate to its culture, competences and current situation, these are: time, scope, preservation, diversity, capability, capacity, readiness and power. This project used the Change Kaleidoscope to appraise the status quo of SC and describe any subsequent design choices. Focus group data were coded aggregated and abstracted into the Change Kaleidoscope's features (shown in Table 2) which form an 'initial calibration' of the 'system-under-observation' (S), and provide insight into 'design choices' for intervention. Once implemented the Change Kaleidoscope can become an audit mechanism of change through subsequent 'recalibrations'.

Table 2: Initial calibration of the Change Kaleidoscope of ' $S$ ' to start design choices 


\begin{tabular}{|c|c|c|c|}
\hline $\begin{array}{l}\text { Context- } \\
\text { Sensitive } \\
\text { Feature } \\
\end{array}$ & $\begin{array}{l}\text { Enabler / } \\
\text { Inhibitor of } \\
\text { Change } \\
\end{array}$ & Status Quo & Design Choices \\
\hline Time & Enabler & Long-term: Several years (Positive) & \multirow{7}{*}{$\begin{array}{l}\text { Change Path: Evolution } \\
\text { and adaptation } \\
\text { Change Start-point: } \\
\text { Top-down } \\
\text { Change Style: } \\
\text { Combination of Directive } \\
\text { (partners to decide on the } \\
\text { changes needed) and } \\
\text { Collaborative (involve } \\
\text { change-affected groups } \\
\text { and individuals in the } \\
\text { design and delivery } \\
\text { process) } \\
\text { Change Levers: Primary } \\
\text { levers - Technical (new } \\
\text { models for pricing, } \\
\text { scoping and client } \\
\text { engagement, new systems } \\
\text { for streamlining routine } \\
\text { procedures). } \\
\text { Secondary lever - } \\
\text { Interpersonal (Soft } \\
\text { systems-based } \\
\text { approaches to bring } \\
\text { together people from } \\
\text { different functions to } \\
\text { share the vision of } \\
\text { improvement) } \\
\\
\text { Change Roles: Internal } \\
\text { change champions } \\
\text { (engage with active and } \\
\text { bought-in individuals to } \\
\text { influence other members } \\
\text { of the department) and } \\
\text { change action teams } \\
\text { (create specific groups of } \\
\text { people working together } \\
\text { on common goals). } \\
\\
\end{array}$} \\
\hline Scope & eutral & & \\
\hline Preservation & Neutral & $\begin{array}{l}\text { In spite of being technologically } \\
\text { advanced, need to retain the level of } \\
\text { personal service to off-the-street client } \\
\text { Preserve the family friendly culture and } \\
\text { ethos of a people-focused firm }\end{array}$ & \\
\hline Diversity & Inhibitor & $\begin{array}{l}\text { Divide between experienced members } \\
\text { who have been there for a long time and } \\
\text { less experienced staff who have the } \\
\text { perceived flexibility and adaptability to } \\
\text { change (negative) } \\
\text { Support staff perceived as not } \\
\text { participative in Change initiative } \\
\text { (negative) } \\
\text { Distinction between fee-earning lawyers } \\
\text { versus non fee-earning staff (negative) }\end{array}$ & \\
\hline Capability & Enabler & $\begin{array}{l}\text { Individual: Perceived lack of individual } \\
\text { adaptability to changes in technology } \\
\text { (negative) }\end{array}$ & \\
\hline Capacity & Neutral & $\begin{array}{l}\text { Cash available (positive) } \\
\text { SC has seen a consecutive increase in } \\
\text { fee income and profits for the last four } \\
\text { years prior to start of the study. } \\
\text { Time of fee-earning lawyers is hard to } \\
\text { buy for non-chargeable work (negative) }\end{array}$ & \\
\hline Readiness & Neutral & $\begin{array}{l}\text { Partners, Associates and Support teams } \\
\text { realise the need for change. (Positive) } \\
\text { The firm as a whole is perceived to lack } \\
\text { the sense of urgency (negative) }\end{array}$ & \\
\hline
\end{tabular}




\begin{tabular}{|l|l|l|l|}
\hline Power & Enabler & $\begin{array}{l}\text { Partners are the power centres for } \\
\text { making key strategic decisions and can } \\
\text { influence change (positive) }\end{array}$ & \\
\hline
\end{tabular}

\subsection{Making Changes - PrOH Modelling Methodology}

Most legal services offered by SC not only involve high degrees of interaction with the client but also require liaising with several other stakeholders outside the firm. To address these operational challenges, that are both complex and soft or humanistic in nature, it was imperative to use radical thinking that transcends the boundaries of traditional thinking (Ackoff, 2006). To deal with these complexities holistic systemic thinking (Jackson, 2006; Paton et al., 2011, p.170-172) was employed, namely PrOH Modelling.

Process Oriented Holonic (PrOH) modelling is a novel methodology developed from principles of SSM for business process redesign (Clegg, 2007). Process mapping techniques are often criticised for being overly reductionist and therefore less effective in modelling human activity systems (HAS) (Checkland, 1981, p.52). The PrOH Modelling Methodology thrives on the shortcomings of conventional process mapping techniques by enabling modellers to elicit intangible systemic success factors and multiple feedback loops. Sampson (2012) argues that there is a pressing need for such new tools like PrOH Modelling as they help to conceptualise, visualise and analyse service operations - because legal services tend to have high human labour intensity and customer contact. In explicating the hidden and emergent properties of systems, subsystems and meta-systems, PrOH Modelling offers an appropriate means of visualising processes in a people-centred system-under-observation (S).

A template of a PrOH model 'holon' (a system that is part of a higher-level system and also contains systems within it), which is the basis of all PrOH models, is presented by Clegg (2007; 
p31). The PrOH Model template is similar in purpose to Checkland's SSM 'root definition' (Checkland and Scholes, 1990) and defines essential parts of systems models, namely: inputs/outputs, data, transformations, systemic success factors, human actors, and their interactions in a process.

This action research built a holarchy (i.e. a set) of $\mathrm{PrOH}$ models to extract and articulate the interactions between people, systems, tangible and intangible entities involved in the delivery of legal services at a departmental and organisational level. The principles of abstraction and enrichment of PrOH Modelling Methodology (Clegg, 2007) developed a set of purposeful activity models revealing systemic success factors of change at SC used in subsequent 'storyboarding' workshops to gain buy-in to systemic success factors for change, leading to action teams of participants developing solutions and then implementing changes to legal service.

\subsubsection{Process Changes in the Dispute Resolution Department}

Five legal department were subject to change in this action research. The Dispute Resolution Department features in detail in this section to demonstrate the action research process. The PrOH model for Dispute Resolution is given in Figure 2 is an exemplar of legal service, DR represents a high-variety and low-volume service representing professional service operations characterised by high degrees of labour intensity, customer interaction and customisation (Schmenner, 1986; Lewis and Brown, 2012). Replication of the same methodology took place in the other four departments; and general conclusive sections of this paper draws on findings from all five departments. 
Dispute Resolution is a complex area of law as it overlaps with many other legal disciplines. Within SC, the case volume is relatively low, and every case is unique, requiring lawyers to tailor solutions to clients' specific requirements and be expert in that niche of law - resulting in high professional work intensity through research and preparation of detailed legal arguments. Dispute Resolution also requires high client interaction making costs of litigation challenging, unpredictable and constantly prone to changes due to unexpected disclosures, unforeseen counterclaims and submission of new expert evidence (Figure 2).

Limited case information at the outset can lead to scope creep, disproportionate costs and a potentially negative experience all round. With these kinds of challenges, the estimation of legal costs is often more art than a science, heavily reliant on experience and judgement. The $\mathrm{PrOH}$ model in Figure 2 demonstrates the systemic success factors of Dispute Resolution (Figure 2). 


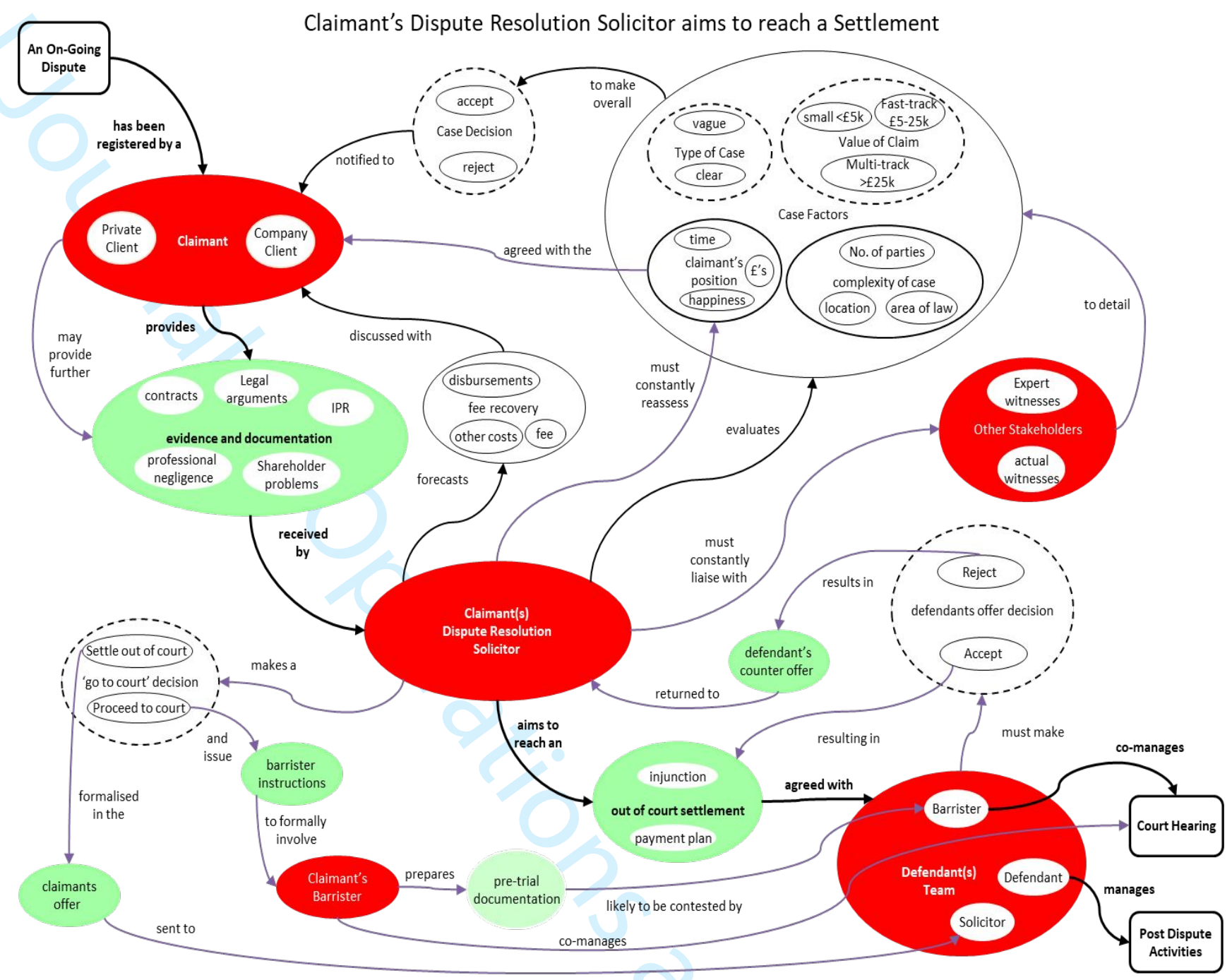

Figure 2: PrOH Model depicting the Dispute Resolution service process

Further elucidation of Figure 2's PrOH Model systemic success factors is in Table 3 for three stakeholder types: the professionals (i.e. lawyers), the clients and the firm alongside the operational challenges for each.

Table 3: Systemic success factors of change in the Dispute Resolution Department

\begin{tabular}{|l|l|l|l|}
\hline \multicolumn{2}{|l|}{ Systemic Success Factors } & & \\
\cline { 1 - 2 } For Lawyer & For Client & For Firm & Operational Challenges \\
\hline
\end{tabular}




\begin{tabular}{|c|c|c|c|}
\hline $\begin{array}{l}\text { Complexity of case- } \\
\text { number of parties involved, } \\
\text { area of law, location of } \\
\text { client, value of claim, } \\
\text { clear/vague documentation, } \\
\text { merits of the case, witnesses } \\
\text { required/not required. } \\
\text { Client type - experience of } \\
\text { litigation, technical } \\
\text { knowledge, easy to advocate } \\
\text { (expect clients to follow the } \\
\text { advice). } \\
\text { Managing client } \\
\text { expectations throughout } \\
\text { (impacts on fee recovery } \\
\text { rate). }\end{array}$ & $\begin{array}{l}\text { Positive outcome - } \\
\text { expected route } \\
\text { (settlement/go to } \\
\text { court), expected } \\
\text { value of settlement. } \\
\text { Lawyer type - } \\
\text { expect lawyer to be } \\
\text { technically sound, } \\
\text { strategic in dealing } \\
\text { with other side. } \\
\text { Cost of litigation- } \\
\text { proportionate to the } \\
\text { value of claim, } \\
\text { transparent. }\end{array}$ & $\begin{array}{l}\text { Profitability } \\
\text { Utilisation }= \\
\text { (Actual Hours } \\
\text { Billed/Total hours } \\
\text { available) } \\
\text { Value = realised } \\
\text { fee per hour } \\
\text { (Fees/Hours) } \\
\text { Productivity = } \\
\text { Value x } \\
\text { Utilisation } \\
\text { Selling additional } \\
\text { services to } \\
\text { clients. }\end{array}$ & $\begin{array}{l}\text { Lack of a standard } \\
\text { pricing, budgeting and } \\
\text { scoping mechanism. } \\
\text { Lack of a formalised } \\
\text { process for factoring in } \\
\text { soft issues such as } \\
\text { managing client } \\
\text { expectations and driving } \\
\text { performance of fee } \\
\text { earners. } \\
\text { Lack of understanding } \\
\text { about the typology of } \\
\text { litigation cases to better } \\
\text { estimate prices. }\end{array}$ \\
\hline
\end{tabular}

Through storyboarding of PrOH models, the Dispute Resolution Department's desirable and feasible process changes were identified, agreed and implemented. Overall, the Dispute Resolution Department found that despite high labour intensity, customer interaction and customisation of its low volume and high variety legal services, there was potential for rationalising processes and improving efficiencies. This was mainly possible by delineating administrative tasks from core legal tasks and more structured client engagement.

\subsubsection{An exemplar tool for the Dispute Resolution Department}

In the Dispute Resolution department, better structure to the initial client engagement process was needed to fully capture case details and arrive at an accurate price quotation. To address this, the Pre-Quotation Fee and Risk Analysis tool was developed. This tool enables lawyers to focus on potentially unknown factors that can impact a case's scope and help visualise, quantify and monetise these to address operational challenges and systemic success factors (given in Figure 3 and Table 3). The tool determines an appropriate fee and serves as an effective negotiation instrument with clients using a visual risk profile based on several case- 
specific factors (litigation value, key parties involved, due diligence and funding). This brought more consistency to lawyer-client interaction so as to leverage analogic communication appropriate for high contact service operations (Chase and Tansik, 1983). In addition, based on case complexity and scope profiled by this tool, legal work distribution to lawyers resulted in better utilisation and higher productivity.

A summary of key changes and new solutions from the Dispute Resolution Department, alongside a summary of those from the four other departments is in Table 4:

Table 4: Tools and solutions developed in each department.

\begin{tabular}{|l|l|l|l|}
\hline Volume & Variety & Department & Solutions delivered through Action Research \\
\hline Low & High & $\begin{array}{l}\text { Dispute } \\
\text { Resolution }\end{array}$ & $\begin{array}{l}\text { Pre-quotation fee and risk analysis tool, Standard } \\
\text { Operating Procedures Guide, Client Transaction Guide. } \\
\text { Other improvements such as standard client care letters, } \\
\text { new client due diligence process, operational best } \\
\text { practice guides were developed and implemented to } \\
\text { reduce administrative burden of lawyers. }\end{array}$ \\
\hline Low & High & Corporate & $\begin{array}{l}\text { Flow of Funds Tool, Scope change indicator, Client } \\
\text { Selection and On-boarding Process }\end{array}$ \\
\hline High & High & $\begin{array}{l}\text { Commercial } \\
\text { Property }\end{array}$ & $\begin{array}{l}\text { Client Engagement Model, Cross selling guide, Work } \\
\text { Allocation Procedure }\end{array}$ \\
\hline High & Low & RTA & $\begin{array}{l}\text { Standard Letters, streamlined billing procedure, reduced } \\
\text { turn-around time (2 weeks) by eliminating bottlenecks }\end{array}$ \\
\hline Firm wide solutions & $\begin{array}{l}\text { Standard Letter templates, Forms and checklists, New } \\
\text { service standards, Revised process flow for production of } \\
\text { Standard Wills (Reduced customer contact), New } \\
\text { Typology of Wills based on complexity, redesigned } \\
\text { existing roles and created a new Case Manager role. }\end{array}$ \\
\hline
\end{tabular}




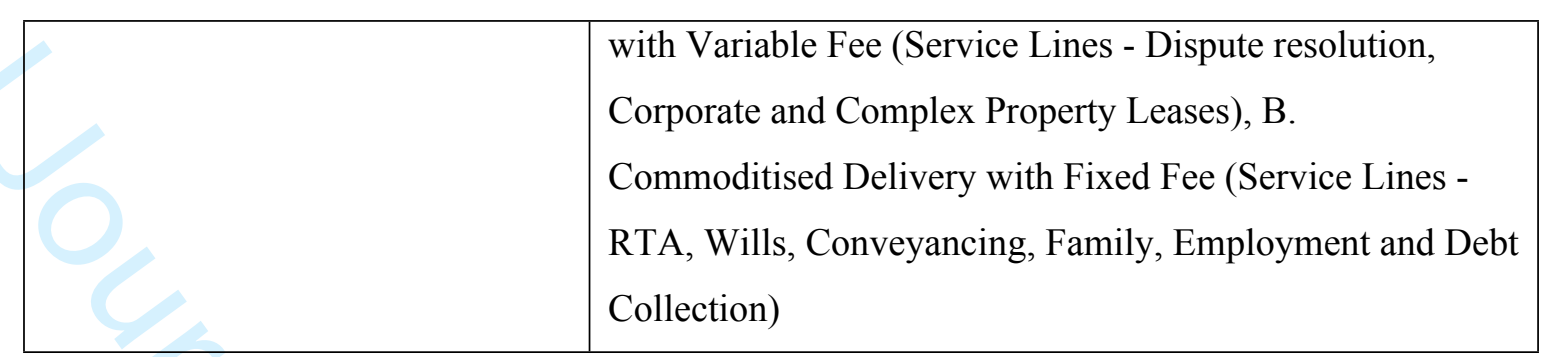

\section{Learning from Intervention: lessons from Solicitors Co.}

This action research methodology $(\mathrm{M})$ intervened in overall SC themes (Table 1) and systemic success factors in each legal service system-under-observation (S) (Figure 2 and Table 3) and used abductive rationalisation to take actions against context-sensitive factors (given in Table 2) from an initial calibration of the Change Kaleidoscope intellectual framework (T). Further discussion of S, M and T in the following sub-sections regards all SC Departments.

In action research, data comes from engagement with participants during action cycles, where the act of collecting data is itself an intervention (Coghlan and Brannick, 2014). As such, observations made during action cycles collect data and simultaneously generate learning for researchers and participants. Lessons in this section use analysis of data collected in formal settings; focus groups, storyboarding workshops and individual consultations a (as outlined in Appendix 1). Section 7.1 directly addresses general SC themes previously defined and presented in Table 1 and associated systemic success factors from different departments (Figure 2 and Table 3).

\subsection{Solicitors Co.: lessons about legal service operations ' $S$ '}

Theme 1: Addressing the need for improving operational efficiency 
Customer involvement in the service delivery process is a source of complexity that can negatively affect efficiency. High contact processes are inherently inefficient and influence the outcome of that service (Chase, 1978; Chase and Tansik, 1983; Shostack, 1984). Two critical perspectives surfaced on this systemic success factor. Firstly, this project demonstrated there is huge potential for making improvements in legal services, “... the project touches on the surface of a lot of areas, it's brought a lot of things to light... it's something that we're constantly assessing" (Dispute Resolution Solicitor). Secondly, efficiency improvement needs to be a continuing effort "...we've improved the billing process, the admin process and that's a good thing. But we've carried on, we haven't stopped there because of changes, particularly in our sphere, going on in legal reforms, we've continued to improve our systems and how we approached things" (Dispute Resolution Solicitor).

The summary of learning generated from Theme 1 is improving efficiency is a continuous endeavour for professionals, which could be capitalised upon to implement large-scale changes across the firm.

\section{Theme 2: Addressing the need for innovative practices in pricing and service delivery}

There is general criticism on current practices on pricing and billing legal work within the legal profession (Susskind, 2013). Hourly billing model is becoming obsolete with more clients demanding accurate and fixed price for the service where accountability for resources and transparency in fees are becoming mainstream expectations.

For example, a lawyer asked “... is it possible for different clients to set up different chargeable rates because some of our time is wasted recalculating rates? Some people have negotiated higher hourly rates and some we work on lower." which indicates there are disparate fee rates 
and ad-hoc approaches leading to misalignment of billable hours and actual hours spent on each case. Another lawyer said "we want to please our clients, we want to please our heads of departments, we want to please ourselves. We want to have positive feedback and you're more likely to get that if you're not writing time off. Sometimes there is a good reason why somebody's time has been particularly written off for example, they've just got it completely wrong, there's no way you can charge the client for that. Yet, we don't monitor write offs in any kind of way" which indicates that there are two facets to the pricing puzzle in law firms, one is accurate pricing and the other, accurate billing for the work carried out (time spent) by the lawyer, which is often a result of poor time capture and write-off practices. The implementation of new tools such as Pre-Quotation Fee and Risk Analysis Tool have brought uniformity to scoping, pricing and billing clients. In implementing these changes, lawyer participation has been of paramount importance as part of the action research team. A list of other similar types of tools developed for other departments is presented in Table 4.

The summary of learning generated from Theme 2 is implementing changes to core processes and practices, such as pricing, requires active contribution of professionals, as professionals can be a source of ideas that change their own practice.

\section{Theme 3: Addressing the need for innovative people management and performance} measurement systems

One of the major barriers for change in this firm was time. Time is a critical resource for lawyers as they operate on hourly billing (each hour divided into ten six-minute units) and account for every minute spent. In this environment, it is difficult to involve lawyers in organisation-wide change initiatives. For instance, a lawyer stated that “...to be brutally honest 
I just didn't have time to do improvement and give it the consideration that I would have liked to on top of all my other commitments".

Some lawyers overcame this hurdle by eliminating long formal meetings and instead arranged brief 'standing-meetings'. In a 'standing-meeting' employees stood-up, shared ideas and proposed solutions for improving specific problem areas (Weisbord and Janoff, 2005; Pot, 2011). Subsequently tasks were delegated and timelines agreed - giving quick, one-to-two week implementation of design changes. Building on initial success further ideas were applied across the firm in other action research cycles to resolve similar problems. One Partner stated “...I was really surprised at how effective it seems to be. We only had about an hour feedback session, and I was really surprised at what was produced" which indicates that participation of professionals in change initiatives can be influenced by effective structured engagement to minimise non-value-added time on any improvement task. Subsequently, a new category called 'investment time' was created for lawyers to book time to while working on organisational change projects which directly feeds into their performance reviews, providing incentive to participate.

The summary of learning generated from Theme 3 is non-chargeable time is a barrier to professionals' engagement in change initiatives and therefore time spent on such activities should be incentivised to gain increased participation.

\section{Theme 4: Addressing the need for a cultural shift towards greater inclusivity across roles} and departments 
Engaging people to take part in firm-wide initiatives is a law-firm challenge. There is a perennial divide between fee-earning staff and the non-fee earning staff, in other words "fee earners versus fee burners" (Forstenlechner et al., 2009), which must be addressed to deliver change.

Cross-functional teams play an important part in innovation and change by enabling crossdiscipline knowledge sharing, development of trust, and the ability to overcome spatial and organizational barriers (Love and Roper, 2009). To access collective knowledge in SC 'action teams' were therefore formed by recruiting members from cross-functional legal and business support departments. Each team was empowered to work autonomously with support from their Head of Department to solve long-standing problems. For instance, one Associate stated that, “...the big advantage was bringing together people who aren't necessarily working together so you may have people from IT and people from the support team and everyone brings their ideas". Working as part of cross-functional action teams diminished power and distance between partners and support staff.

The summary of learning generated from Theme 4 is forming cross-functional teams comprised of legal and support professionals fosters innovation and accentuates the delivery of change.

\section{Theme 5: Addressing the need for developing skills and capabilities in engaging wider groups}

The PrOH Modelling Methodology helped improve awareness and appreciation of process improvement. It enabled SC employees to reflect on current processes and become creative 
improvers, partly due to the change process involving a mixture of one-to-one interviews, storyboarding sessions and standing meetings. Reflection enabled 'double-loop learning' to question the underlying metrics and assumptions in ' $\mathrm{S}$ ' rather than simply mending effects (Argyis and Schon, 1978). This can be observed from the words of a Partner who stated that, “...things like open discussions make people think about what can we do better? Thinking around themselves is important".

PrOH modelling was used as a facilitative and negotiative device (Eden, 1995) in storyboard workshops to stimulate more in-depth and broader, critical and reflective thinking through structuring, connection, synthesis, negotiation, evaluation and building of collective knowledge (Shaw et al., 2004). Narrating the whole process in a simple storyboarding fashion enabled the action research team to engage staff to reflect on current processes and identify potential improvements for delivering higher valued services.

The summary of learning generated from Theme 5 is that systemic approaches to change management, through PrOH Modelling, fosters a culture of reflective practice and continuous improvement among professionals.

\subsection{Lessons on action research $(\mathrm{M})$}

A challenge invariably faced by researchers during action research is the extraction of learning from action, also called reflection, and the process of doing this - defined a posteriori as 'reflection-on-action' - as opposed to Schon's (1983) 'reflection-in-action' that is simultaneous and more abductive. Reflection-in-action, or abductive rationalisation, can be difficult to 
conceptualise, and action researchers have indicated that this contemporaneous process, although distinct from, could yet be often confused with, reflection-on-action (Schon, 1983), and that the former remains a concept needing further investigation. For example, Yanow and Tsoukas (2009) ask, "How can reflection-in-action theorizing overcome its cognitivist bias?' and "What would it look like when doing so?" These issues are central to the use of abductive research in participatory action research and addressed below.

Action research operates in contrast with positivist approaches and hence open to researchers' cognitivist bias (Susman and Evered, 1978). The basis of validation in action research is the conscious and deliberate enactment of the action research cycle (Coughlan and Coghlan, 2002) involving the action researcher and those subjects observed and actioned on. There is significant emphasis within action research literature on the role and conduct of the action researcher, for example Gummesson (2000) laid out the characteristics of the researcher's role in action research which demands a certain prior knowledge of the problem situation. Argyris and Schon (1974, p.221) even refer to action research as 'action science' and call for 'consciousness in the midst of action' on the part of the researcher as a fundamental tenet of action enquiry. In order to illustrate further on the role of researcher in action research we propose a new term, the 'situated-reflective-agent', as a development to the term 'action researcher', to address the issue of cognitivist bias, and an increased use of abductive rationalisation to better perform reflection-in-action. The term 'situated' refers to an agent embedded in an environment. We posit that human agents embedded in a 'problem situation' should be situated, reflective and abductive in nature, and hence a new term, the 'situatedreflective-agent' should be coined to better reflect this position. 
Figure 3 presents a new model rooted in the idealistic philosophy of Husserl (1982) and Heidigger (1962), explaining how the identity of the participatory action researcher evolves from an initial outsider (at point A), detached from the problem situation, to that of 'going native' with the participating organisation (at Point B), and finally emerging as a SituatedReflective-Agent (at point C, Figure 3).

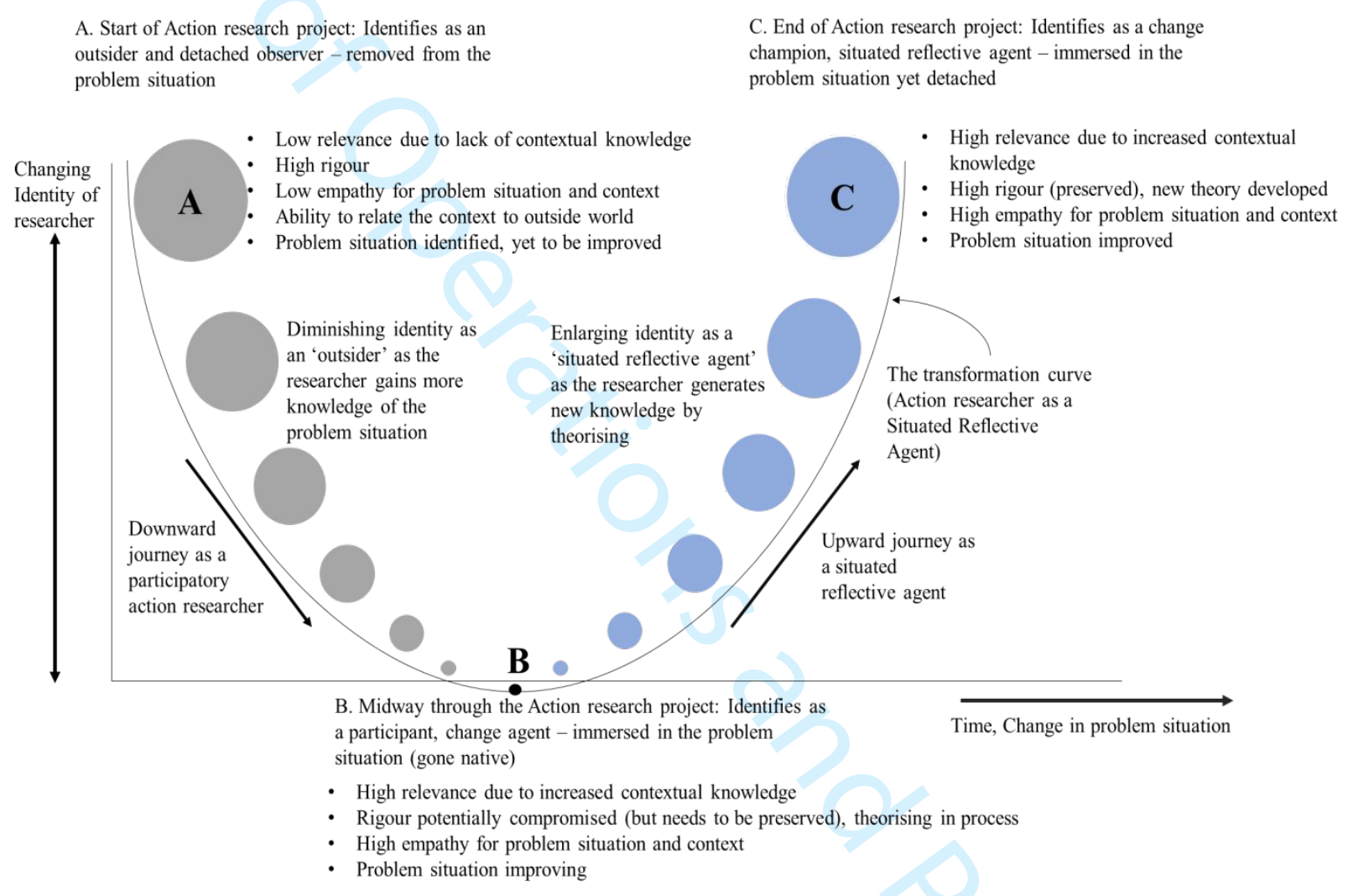

Figure 3: Evolving identity of the action researcher into a 'Situated-Reflective-Agent'

Literature emphasises on the political dimension of action research that can undermine research endeavours, affect research quality and block planned change. For example, Cooklin (1999) refers to the insider change agent as the 'irreverent inmate', one who is a supporter of the people in the organization, a saboteur of the organization's rituals and a questioner of some of its beliefs. In SC the journey from Point A to B involved dealing with SC Partners with strong 
agenda to bring consistency and uniformity of practices across departments that meant that the researcher had to attend to issues perceived to be more pressing by the Heads of Departments even if it meant a deviation in project's scope. In other words, there was a conflict between the actual needs of individual departments as opposed to the wants of the Partners. This has been observed by previous researchers who noted that PSFs are like “... a fashionable store - a flash brand on the outside with a lot of franchises on the inside" (Morris and Malhotra, 2002 p.16), or where management is rather like trying to, “...make ten or twenty race horses pull a cart together" (Lowendahl, 1997 p. 63).

This research therefore proposes that a 'situated-reflective-agent' is initially a detached observer (at Point A, Figure 3) which is akin to Schein's (1999) pure inquiry. Going through a cognitive journey as a participatory action researcher, the 'outsider' and 'detached observer' identity reaches Point B where the researcher is fully engaged and immersed with the problem situation while empathising with other participants and acting as an agent of change. At this stage, the researcher potentially goes 'native' that might compromise knowledge creation, as they become fully immersed in taking action to improve the situation. This is where the researcher must remember to lean heavily on the objectivity of a theoretical framework (e.g. the Change Kaleidoscope). From here, the researcher has to continue the journey of reemergence where reconciliation of both 'outsider' and 'native' views develop a 'situatedreflective-agent' who is immersed in action to improve the problem situation but yet reflectingin-action to create new knowledge. Point $\mathrm{C}$, on the situated-reflective-agent transformation curve shown in Figure 3, indicates the transformation of a researcher's weltanshauung. The researcher, once having been a detached observer transformed into an immersed action taker, to that of a holistic thinking situated-reflective-agent, has now experienced praxis, been enlightened by theory and potentially induced some theory development. At Point $\mathrm{C}$ a 
researcher may be considered to have undertaken the full situated-reflective-agent journey curve.

We propose that achieving situated-reflective-agency is the ideal state of an action researcher to ensure both rigour and relevance (at Point C, Figure 3). Inculcating situated-reflectiveagency invariably requires knowing one is going through stages from $\mathrm{A}$ to $\mathrm{B}$ to $\mathrm{C}$ as presented in this new model, in Figure 3, as it represents key stages of action researchers' transformation. The whole endeavour of situated-reflective-agency is about overcoming cognitivist biases to deliver relevant action, be aware of existing knowledge, and have the ability to generate new rigorous and credible knowledge. The authors believe that this becomes stronger if action research cycles are done in parallel rather than in sequence - as in the case of SC - as change in different departments were happening simultaneously. This accelerated learning and reflection-in-situation happens because a researcher is rationalising against a known intellectual framework in-situ from various sub-cases (e.g. 5 departments) which reduces bias. Coordinated by a cross-departmental action research team and implemented by employees from each department, action within each parallel cycle accelerated adoption and impact of change. PrOH modelling can present this by being able to model parallel and serial departmental activities and form sets of models through holistic abstraction and enrichment of holon based models - a modelling property unique to PrOH modelling.

There are various other suggestions from authors about ensuring quality in action research. For example: four quality dimensions of organization development through action research (Coghlan and Shani, 2014); five quality criteria proposed by Heikkinen et al (2007); 15 characteristics of good action research (Eden and Huxham, 2006), and three criteria of rigour, 
reflection and relevance by Pasmore (2008) etc. Bradbury-Huang (2010) advocates that quality:

- proceeds from a praxis of participation: this research involved a consultative approach where employees and partners participated in the design and delivery of solutions to organisational problems (Table 1).

- is guided by practitioners' concerns for practicality (real-life problems): organisational issues of practical importance were identified with the help of lawyers and managers in the initial data gathering interviews and meetings (Table 3).

- is inclusive of stakeholders' ways of knowing (joint-meaning construction): $\mathrm{PrOH}$ modelling storyboards and focus groups facilitated consensus building and jointmeaning construction in departmental improvement activities (Table 3).

- helps to build capacity for ongoing change efforts (workable solutions): numerous practical solutions have been designed and implemented in the firm (Table 4).

These action research quality principles, especially those of Bradbury-Huang (2010) and Reason (2006), have been adhered to in this action research as explained above and evidenced throughout this paper.

\subsection{Lessons on the intellectual framework $(T)$ - the Change Kaleidoscope}

In this study, the Change Kaleidoscope was an intellectual framework used to appraise, design and subsequently monitor change in SC. The initial phase of this action research involved calibration of the Change Kaleidoscope's eight context-sensitive features, firstly to establish design choices for planning change (Table 2) and subsequently, once changes were implemented, the Change Kaleidoscope allows for retrospective analysis and a deeper understanding of change outcomes achieved (Hope-Hailey and Balogun, 2002). Such lessons 
can enable researchers and professionals to better design and implement future change initiatives. According to the authors, analysis of the contextual features at the beginning of the change programme will not automatically offer the right design choices (although it is likely to reveal the wrong ones). Retrospective analysis of design choices presented in this section, therefore help to elicit gaps in organisation's cultural context at the beginning of this exploratory study. A juxtaposition of design choices adopted at the beginning and those that were emergent during the action research process leads to a rich understanding of both the methodology (action research) and the system under observation (legal service operations). In effect, this double loop learning (Argyis and Schon, 1978) allows reflection upon assumptions and criteria (design choices) based on which the action was planned. In addition, this reflection on design choices before and during the change process will explicate participants' 'theory in use' rather than their 'espoused theory' (Argyris and Schon, 1974) which is a characteristic feature of action research.

This section presents lessons on using the Change Kaleidoscope 'intellectual framework', under the broad headings of design choices that played a crucial role in the overall change design and implementation. With particular focus on how design choices made at the beginning of the project evolved and corrective actions applied as a result of submergence and immersion in the case organisation as Point B in Figure 3 is experienced.

\subsubsection{Change Start-point and Change Style}

Initially the ideal change start-point within $\mathrm{SC}$ was perceived to be top-down change as previous experience of major changes in the organization such as the office move and implementation of a customer relationship management (CRM) system indicated that the change was initiated and implemented through a top-down approach anchored by the firm's 
senior management. Whereas in this action research it became evident that bottom-up change was indispensable and was often the most practically grounded start-point. Such change was initiated by the pressing need for improvement in cumbersome administrative processes (e.g. case opening, billing) mainly by paralegals and support staff.

\begin{abstract}
Although Partners and Heads of Departments were central to facilitating overall implementation of change and seen as the center of power enabling change, it was the professionals and support staff that were instigating it, “...Some have had more influence than others maybe within teams, but I think on the whole it's very much been a team-based drive." -Solicitor.
\end{abstract}

Moreover, a law firm can be seen as an agglomeration of different service lines (departments) with Heads of Departments having autonomy in the way they conduct their department, a phenomenon that aligns with observations of previous researchers that "PSFS are organisationally fragmented" (Alvesson and Karreman, 2004). Such an organisational structure has implications for the way change is managed in the firm and where it originates, for example, throughout the five parallel Departmental action research cycles it was observed that sharing of pockets of good practice has been a start-point for change, which was facilitated through focus groups (inter-departmental) particularly $\mathrm{PrOH}$ modelling storyboarding sessions (intra-departmental). This phenomenon was further accentuated by the way PrOH Modelling was carried out, which hinged on the parallel abstraction-and-enrichment as opposed to the serial abstraction-and-enrichment (Clegg, 2007; Clegg and Shaw, 2008) of PrOH models pitched at the same level but connecting disparate departments to explore the strategic changes that can be made at the firm-level. 
Similarly Change Style was initially perceived to be a combination of Directive (Partners deciding the changes needed) and Collaborative (involve change-affected groups and individuals in the design and delivery process) approaches. This was also seen to have adjusted over the course of action research to reflect a more collaborative approach. It was observed that although Partners articulated the high-level changes needed in respective departments, it was only after consultation with staff which involved at least 5-6 interviews lasting for 60-75 minutes within each department, that actual issues were identified that subsequently led to implementation of changes, “...I can see this project is supported by the partners. So that assists me with moving toward changes, and for partners to make allowances for one to have the time needed to do what you've got to do". -Associate.

\subsubsection{Change Levers}

The initial understanding of change levers at SC were seen as Technical (new models for pricing, scoping and client engagement, new systems for streamlining routine procedures) and Interpersonal (soft systems based approaches to bring together people from different functions to share the vision of improvement), and accordingly the change intervention was structured to reflect these approaches. In the course of implementation, it was observed that a gamut of other levers were developed and dynamically adapted as a result of new ideas and demands brought in by professionals through their active participation. For example, some of the new levers used in the process of effecting change included standing meetings and new prototype tools which were not part of the original plan. "Some of the tasks you could bash it out with members of your team and just get your ideas down and within 15 minutes you'd ticked one off"'-Solicitor. 
In addition, communication and knowledge dissemination are other levers that played a significant role in bringing together people to participate in change initiatives. Due to popular demand, the action research team consistently communicated findings from each stage, through a series of high-quality consultancy report-style publications that were released firm wide.

\subsubsection{Change Roles}

Change roles were initially given to Internal Change Champions (active and bought-in individuals to influence other members of the department) and change action teams (specific groups of people working together on common goals). These roles anchored changes in each department, which met with some pockets of resistance but largely succeeded. In this process it was clear that change would not be sustainable without external facilitation by academic experts in the action research team - because support departments and core legal departments either lacked the capability and/or capacity, An Associate stated that, "A real co-ordinated central approach, supported with external expertise, is required to make sure that changes are actually put into practice ... without such an approach researchers and partners may simply talk about great ideas without actually seeing any result"-Associate.

It is clear that this action research initiative was a vehicle for innovative change within SC. Consequently, it was imperative for the firm to create a new culture and function of "change management' that is centrally situated and exclusively responsible for designing and implementing change, that would replace the temporary action research team. This was subsequently implemented as the firm created an 'Organisational Change and Projects Manager' role supervised by a Partner-level change champion solely assigned to deal with firm-wide change projects in the future. 
At the organisational level, the lessons presented above articulate complex hidden factors, which emerged out of the change process which provided an incentive for participants to spend time (Eden and Huxham, 1996) on future change initiatives in SC. At an operational level, lessons highlight good practice for Change Kaleidoscope application in legal service operations, which is a complex professional service where context-sensitive features can undermine efficiency (Goodale et al. 2008; Lewis and Brown, 2012).

\section{Summary: conducting effective action research in professional services}

This action research project has produced a substantial body of work that comprised dozens of interviews, focus groups and workshops conducted with staff at all levels over two years. Numerous practically implementable ideas and working prototypes have been developed and rolled out within individual departments and at the firm level. This presented the firm with an opportunity to deliver a number of changes to practice that improved the overall financial and operational performance. Alongside ideas and working prototypes, the firm gained collective readiness for change as well as the capability to achieve it in shorter time.

After implementing operational changes and engaging with over $30 \%$ of staff members at various stages of the action research: such as involving them in focus group discussions, PrOH model storyboarding sessions, one-to-one interviews, standing meetings, action teams etc., a survey was conducted to monitor the increased propensity towards change. The sample size of the survey $(n=180)$ included all staff members out of which 97 participated giving a response rate of $54 \%$. From the results in Figure 4, there is evidence to state that, participation in these action research activities improved the orientation of people towards operational improvement and wider organisational change. Figure 4 shows the increased 
propensity for change in each of the context sensitive features of the Change Kaleidoscope.

The data collection tool used for Figure 4 is presented in Appendix 2.

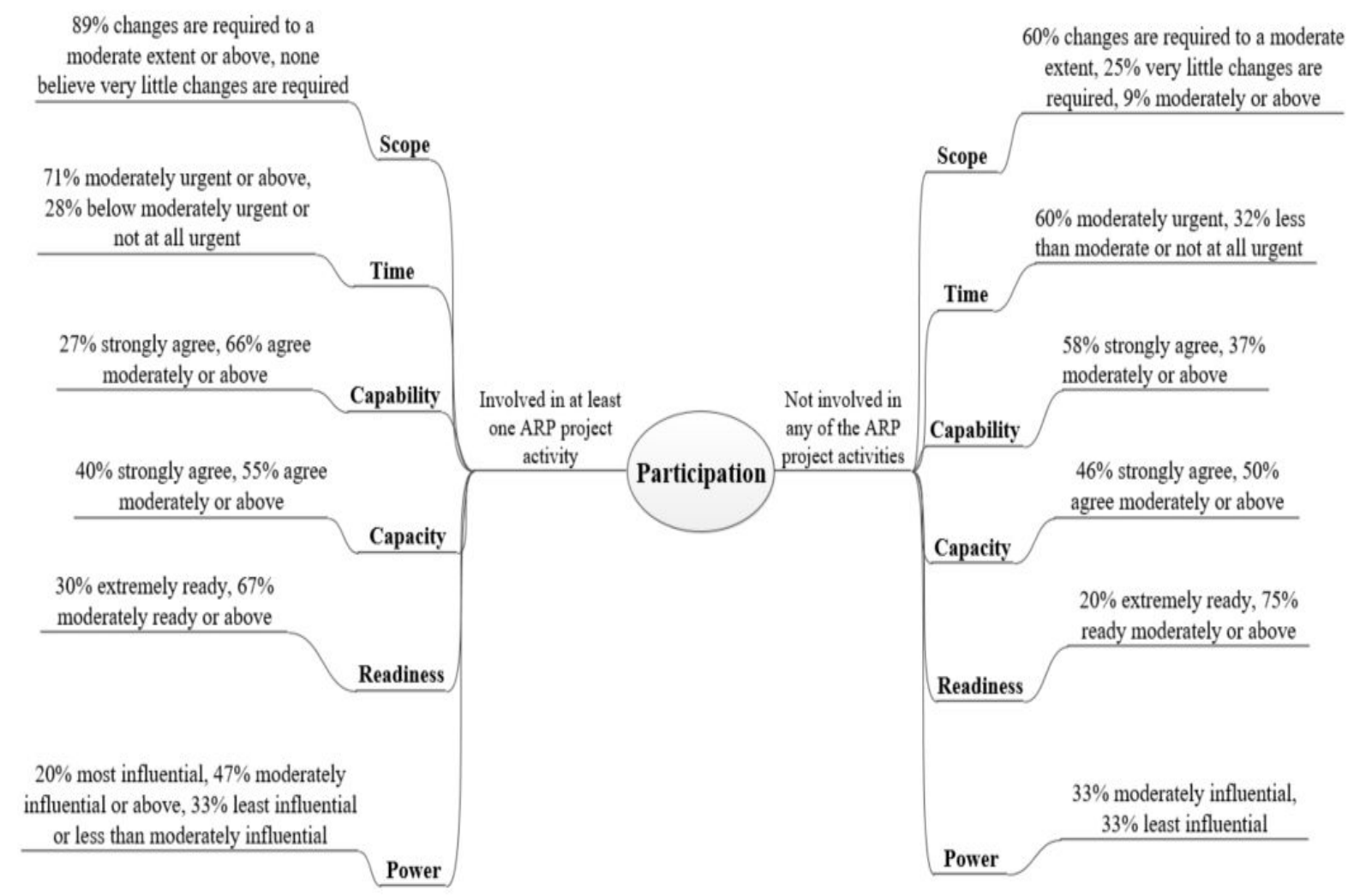

Figure 4: Survey responses categorised based on involvement in the action research process

This paper informs practitioners how to implement effective change in a complex-evolving industry of legal services (Susskind, 2013) and more broadly professional services (Christensen et al, 2013). Specifically, this study highlighted some good practices and learnings from the application of action research, the PrOH Modelling Methodology and, the Change Kaleidoscope in a professional service firm. 
The contributions of this research are three-fold. Firstly, this study presented themes and factors to consider in managing professionals and professional service operations - and shown design choices (operational process and tools) to give greater efficiency and effectiveness (S), which is a contribution to practice. Secondly, this study has evolved action research processes (M) by presenting the situated-reflective-agent journey curve and novel parallel and serial holistic modelling properties of the PrOH methodology to accelerate learning. Thirdly, it presents a critical reflection on the Change Kaleidoscope intellectual framework (T) used in the intervention to design change. Three-fold insight is therefore delivered for future research into professional service operations management. In addition, this research also contributes to the recent emergence of intervention-based research literature (Oliva, 2019; Chandrasekaran et al., 2020) and the calls for more empirically based theory development using abductive rationalisation in action research - an implicit call that has existed for decades in the field of OM (Westbrook, 1995; Eden and Huxham, 1996; Coughlan and Coghlan, 2002).

This research is limited to in-depth study of a single law firm but demonstrates how application of action research interventions may create wider positive impact on mid-sized law firm operations in the UK. There is further potential to consider that a similar approach could be applicable in other forms of professional service operations management. 


\section{References}

Ackoff, R.L. (2006), Why Few Organizations Adopt Systems Thinking. Systems Research and Behavioural Science, Vol.23 pp.705-708.

Alvesson, M and Karreman, D (2004), Interfaces of control. Technocratic and socio-ideological control in a global management consultancy firm, Accounting, Organizations and Society, Vol.29 No.3, pp.423444

Argyris, C., and Schon, D. (1974), Theory in practice: Increasing professional effectiveness. San Francisco: Jossey Bass.

Argyris, C., and Schon, D. (1978), Organizational learning: A theory of action perspective. Reading, MA: Addison-Wesley.

Balogun, J. and Hope-Hailey, V. (2008), Exploring Strategic Change. London: Prentice Hall.

Blau, P.M., and Scott, W.R. (1962), Formal organizations: a comparative approach. Chandler.

Bradbury-Huang, H. (2010) 'What is good action research?: Why the resurgent interest?', Action Research, Vol.8 No.1, pp.93-109.

Chase, R. B. (1978), Where Does the Customer Fit in a Service Operation? Harvard Business Review, 56, 6, pp.137-142.

Chase, R.B and Tansik, D.A (1983), The Customer Contact Model for Organization Design, Management Science, Vol.29 No.9, pp.1037-1050.

Checkland, P.B. (1981), Systems thinking, systems practice. Chichester: Wiley

Checkland, P and Poulter, J (2006), Learning for Action: A Short Definitive Account of Soft Systems Methodology and its Use, for Practitioners, Teachers and Students. John Wiley and Sons Ltd, Chichester.

Checkland, P and Scholes, J (1990), Soft systems methodology in action, Wiley.

Clegg. B.T, Balthu, K.C. and Morris, G (2020), Changing professional service archetypes in a law firm using Process Orientated Holonic ( $\mathrm{PrOH})$ Modelling, Knowledge Management Research \& Practice, Vol.18 No.1, pp.38-52.

Clegg, B.T. (2007), Building a Holarchy using Business Process Orientated Holonic (PrOH) Modeling. IEEE Systems, Man and Cybernetics: Part A, Vol.31 No.1, pp.23-40.

Clegg, B. and Shaw, D., (2008), Using process-oriented holonic (PrOH) modelling to increase understanding of information systems. Information Systems Journal, Vol.18 No.5, pp.447-477.

Chandrasekaran, A., Treville, S. and Browning, T. (2020), Editorial: Intervention-based research (IBR)What, where, and how to use it in operations management, Journal of Operations Management, Vol.66 No. 4, pp.370-378.

Christensen, C. M., Wang, D. and Bever, D. van (2013), Consulting on the Cusp of Disruption, Harvard Business Review, Vol 91 No. 10, pp.106-114.

Coghlan, D. and Brannick, T. (2014) Doing action research in your own organization. 4th edition. SAGE.

Coghlan, D. and Shani, A. (2014) 'Creating Action Research Quality in Organization Development: Rigorous, Reflective and Relevant', Systemic Practice \& Action Research, Vol.27 No.6, pp.523-536.

Cooklin, A. (1999). Changing organizations: clinicians as agents of change. Karnac Books.

Cooper, D.J., Hinings, B., Greenwood, R., and Brown, J. (1996), Sedimentation and transformation in organizational change: The case of Canadian law firms. Organizational Studies, Vol.17 No.4, pp.623647.

Coughlan, P. and Coghlan, D. (2002), Action research for operations management, International Journal of Operations and Production Management, Vol.22 No.2, pp.220-240.

Eden, C. (1995), Using cognitive mapping for strategic options development and analysis (SODA). In: Rational Analysis for a Problematic World, Rosenhead, J. (ed.), pp.21-42. Wiley, Chichester, UK.

Eden, C. and Huxham, C. (1996) 'Action Research for Management Research', British Journal of Management, Vol.7 No.1, pp.75-86.

Empson, L., and Chapman, C. (2006), Partnership versus Corporation: Implications of Alternative Forms of Governance in Professional Service Firms. In R. Greenwood, and R. Suddaby, Research in the Sociology of Organizations: Professional Service Firms (pp.139-170). Oxford: Elsevier.

Empson, L. (2007), Managing the modern law firm: new challenges, new perspectives. Oxford University Press 
Ertel, D. and Gordon, M., (2012), Points of Law: Unbundling Corporate Legal Services to Unlock Value. Harvard Business Review, Issue Jul-Aug, pp.126-133.

Falconer, L. (2005). The Future of Legal Services: Putting Consumer First, Norwich: Department of Constitutional Affairs.

Freidson, E. (2001), Professionalism: The third logic, University of Chicago Press, Chicago.

Forstenlechner. I, Lettice.F, and Tschida. M, (2009), Fee earner vs fee burner: internal divides in law firms. Employee Relations, Vol.31 No.1. pp.98-113

Giannakis, M. et al. (2018), 'The design and delivery of modular legal services: implications for supply chain strategy', International Journal of Production Research, Vol.56 No.20, pp.6607-6627

Goodale, J. C., Kuratko, D. F. and Hornsby, J. S. (2008), Influence factors for operational control and compensation in professional service firms, Journal of Operations Management. Vol.26 No.5, pp.669688.

Gummesson, E, (2000), Qualitative Methods in Management Research. Thousand Oaks, Calif: SAGE Publications, Inc.

Hayes, R.H. and S.C. Wheelwright. (1979a), Link manufacturing process and product life cycles. Harvard Business Review, Vol.57 No.1, pp.133-140.

Hayes, R.B., and Wheelwright, S.C. (1979b). The dynamics of process-product life cycles, Harvard Business Review, Vol.57 No.2, pp.127-136.

Harvey, J., Heineke, J. and Lewis, M. (2016), Editorial for Journal of Operations Management special issue on Professional Service Operations Management (PSOM), Journal of Operations Management, Vol.42-43, pp.4-8.

Heidegger, M. (1962). Being and Time. New York: Harper and Row.

Heikkinen, H. L. T., Huttunen, R. and Syrjala, L. (2007) Action research as narrative: five principles

for validation, Educational Action Research, 15(1), 5-19.

Hope-Hailey, V. and Balogun, J. (2002), Devising Context Sensitive Approaches To Change: The Example of Glaxo Wellcome, Long Range Planning, p.153.

Husserl, E. (1982). Ideas pertaining to a pure phenomenology and to a phenomenological philosophy (F. Kersten, Trans.). The Hague, the Netherlands: Martinus Nijhoff.

Jackson, M. C., (2006), Creative Holism: A Critical Systems Approach to Complex Problem Situations. Systems Research and Behavioural Science, Volume 23, pp.647-657.

Jaakkola, E, (2011), Unraveling the practices of "productization" in professional service firms, Scandinavian Journal of Management, Volume 27, Issue 2.

Kaiser, S. and Ringlstetter, M. (2011), Strategic Management of Professional Services Firms: Theory and Practice. London: Springer.

Lorsch, J. W. and Mathias, P. F. (1987), When professionals have to manage, Harvard Business Review, Vol.65 No.4, pp.78-83.

Love, J. H. and Roper, S. (2009), Organizing innovation: complementarities between cross-functional teams, Technovation, Vol.29 No.3, pp.192-203.

Løwendahl, B. (1997), Strategic management of professional service firms. Copenhagen: Copenhagen Business School Press.

Legal Services Act 2007. http://www.legislation.gov.uk/ukpga/2007/29/introduction.

Lewis, M. and Brown, A. (2012), How different is professional service operations management, Journal of Operations Management, Vol.30 No,1-2, pp.1-11.

Machuca, J., Gonzalez-Zamora, M.d.M., and Aguilar-Escobar, V.G. (2007), Service operations management research. Journal of Operations Management, Vol.25 No.3. pp.585-603.

March, J. G. (1981), Footnotes to organizational change. Administrative Science Quarterly, Vol.26, pp.563-577.

Morris, T., and Malhotra, N. (2002). Towards managerialism: Analysing the process of change in professional service organisations. Paper presented at the $4^{\text {th }}$ biennial workshop on professional service firms, Alberta, August.

Nohria, N. and Beer, M. (2000), Cracking the Code of Change, Boston: Harvard Business School.

Nordenflycht, A.V. (2010), What is a Professional Services Firm? Towards a Theory and Classification, Academy of Management Review, Vol.35 No.1, pp.155-174.

Oliva, R. (2019), Intervention as a research strategy, Journal of Operations Management, Vol.65 No.7, pp.710-724. 
Pasmore, W., Woodman, R. and Simmons, A. (2008), Toward a more rigorous, reflective, and relevant science of collaborative management research. In Handbook of collaborative management research (pp. 567-582). SAGE Publications, Inc.

Paton, S., Clegg, B., Pilkington, A., and Hsuan, J. (2011), Operations management. McGraw-Hill Higher Education.

Pinnington, A, and Morris, T. (2003), Archetype Change in Professional Organizations: Survey Evidence from Large Law Firms. British Journal of Management. Vol.14 No.1, pp.85-99.

Pot, F., (2011), Workplace innovation for better jobs and performance. International Journal of Productivity and Performance Management, Vol.60 No.4, pp.404-415.

PwC, (2018), Resilience through change: PwC Law Firms' Survey 2018. [Online] Available at: https://www.pwc.co.uk/industries/law-firms/pwc-law-firms-survey-report-2018-final.pdf

Reason, P. (2006), Choice and quality in action research practice. J. Manage. Inq., Vol.6 No.15, pp.187203.

Sampson, S. E. (2012), Visualizing Service Operations. Journal of Service Research, 15(2), pp.182-198.

Sampson, S. (2020). A Strategic Framework for Task Automation in Professional Services. Journal of Service Research, Vol.24 No.1 pp.1-19.

Schein, E.H. (1999), Process Consultation Revisited, Building the Helping Relationship, Addison-Wesley, reading, MA.

Schmenner, R. W. (1986). How Can Service Businesses Survive and Prosper?. Sloan Management Review. Vol.27 No.3, pp.21-32.

Schmenner, R.W., (2004), Service businesses and productivity. Decision Sciences Vol.35 No.3, pp.333347.

Schon, D. A. (1983). The reflective practitioner. London, England: Temple Smith.

Shaw, D., Westcombe, M., Hodgkin, J. and Montibeller, G. (2004), Problem structuring methods for large group interventions, The Journal of the Operational Research Society, Vol.55 No.5, pp.453-463.

Sherer, P, and Lee, K. (2002), Institutional change in large law firms: A resource dependency and institutional perspective, Academy of Management Journal. Vol.45 No.1, pp.102-119

Shostack, G. L. (1984), Designing services that deliver, Harvard Business Review, Vol.62 No.1, pp.133139.

Silvestro, R., Fitzgerald, L., Johnston, R. and Voss, C. (1992). Towards a classification of service processes. International Journal of Service Industry Management, Vol.3 No.3, pp.62-75.

Sonenshein, S. (2010), We're changing-or are we? Untangling the role of progressive, regressive, and stability narratives during strategic change implementation, Academy of Management Journal, Vol.53 No.3, pp.477-512.

Susskind, R. E. (2013), Tomorrow's lawyers: an introduction to your future, Oxford University Press.

Weisbord, M. and Janoff, S., (2005), Faster, shorter, cheaper may be simple: It's never easy. The Journal of Applied Behavioural Science, Vol.41, pp.1-13.

Westbrook, R. (1995), Action research: a new paradigm for research in production and operations management, International Journal of Operations and Production Management, Vol.15 No.12, pp.6-20.

Yanow, D. and Tsoukas, H. (2009), What is Reflection-In-Action? A Phenomenological Account, Journal of Management Studies, Vol.46 No.8, p.1339-1364. 


\section{Appendix 1: Data Gathered}

\begin{tabular}{|c|c|c|c|}
\hline \begin{tabular}{|l|} 
Timeline \\
(Project \\
Duration = 24 \\
months)
\end{tabular} & $\begin{array}{l}\text { Data Collection } \\
\text { Method }\end{array}$ & Source & Purpose \\
\hline Month 2-3 & $\begin{array}{l}\text { Focus Groups } \\
\text { (Recorded and } \\
\text { transcribed) }\end{array}$ & $\begin{array}{l}\text { Cross Sectional focus groups x } 5 \\
\text { Sampling: Participants drawn } \\
\text { from all levels in the firm - } \\
\text { Secretaries, Paralegals, Solicitors, } \\
\text { Associates, Partners, and Support } \\
\text { Staff. } \\
\text { Number of Participants = } 21\end{array}$ & $\begin{array}{l}\text { To establish the need for } \\
\text { change in legal services } \\
\text { and design appropriate } \\
\text { intervention for change }\end{array}$ \\
\hline Month 3-18 & $\begin{array}{l}\text { Staff Interviews } \\
\text { (Recorded but not } \\
\text { transcribed, used only } \\
\text { to refer to notes) }\end{array}$ & $\begin{array}{l}\text { Sampling: Key stakeholders } \\
\text { including lawyers and support } \\
\text { staff from each department during } \\
\text { intervention. } \\
\text { Number of Participants }=30\end{array}$ & $\begin{array}{l}\text { To understand the process } \\
\text { flows, and the key issues in } \\
\text { each department. Develop } \\
\text { process maps and PrOH } \\
\text { models. }\end{array}$ \\
\hline Month 10 & Online Questionnaire & $\begin{array}{l}\text { Firm wide staff }(\mathrm{n}=180) \\
\text { Number of Participants }=97\end{array}$ & $\begin{array}{l}\text { To review the impact of } \\
\text { change using Change } \\
\text { Kaleidoscope framework, } \\
\text { mid-way through the } \\
\text { project. }\end{array}$ \\
\hline Month 4-18 & $\begin{array}{l}\text { PrOH Modelling } \\
\text { Storyboarding } \\
\text { Workshops } \\
\text { (Recorded but not } \\
\text { transcribed, used only } \\
\text { to refer to notes) }\end{array}$ & $\begin{array}{l}\text { Departmental workshops x } 5 \\
\text { Sampling: Key stakeholders } \\
\text { including lawyers and support } \\
\text { staff from each department during } \\
\text { intervention. } \\
\text { Number of Participants }=25\end{array}$ & $\begin{array}{l}\text { To elicit the areas of } \\
\text { improvement in each } \\
\text { department and develop } \\
\text { consensus for change } \\
\text { implementation. }\end{array}$ \\
\hline Month 19 & $\begin{array}{l}\text { Focus Groups } \\
\text { (Recorded and } \\
\text { transcribed) }\end{array}$ & $\begin{array}{l}\text { Cross sectional focus groups } \mathrm{x} 4 \\
\text { Sampling: Participants drawn } \\
\text { from all levels in the firm }- \\
\text { Secretaries, Paralegals, Solicitors, } \\
\text { Associates, Partners, and Support } \\
\text { Staff. } \\
\text { Number of Participants }=39\end{array}$ & $\begin{array}{l}\text { To review the impact of } \\
\text { change, understand current } \\
\text { issues across other non- } \\
\text { participating departments, } \\
\text { and consolidate findings } \\
\text { from Action research to } \\
\text { develop future direction. }\end{array}$ \\
\hline
\end{tabular}




\section{Appendix 2: Staff Survey Questionnaire}

1 . What is your role in the firm?

- Options with all different role titles in the firm (e.g. Equity partner, Solicitor, Secretary etc.)

2. How long have you been working at SC?

- Less than 5 years

- Between 5 and 10 years

- More than 10 years

3. Were you directly involved in the action research project e.g. participating in an action team, focus group? Or directly affected by the outcomes of this project?

- $\mathrm{Yes} / \mathrm{No}$

4. Given the changes in the legal sector how much does SC need to change in order to sustain its success?

- On a scale of 1 - 5 (Little needs changing to Everything needs changing)

- Open text box to describe what needs to be preserved from being changed.

5. How quickly should this change take place within SC?

- On a scale of 1 - 5 (Not urgent at all to Extremely urgent)

6. SC has the people capable of achieving the required changes?

- On a scale of 1 - 5 (Strongly disagree to Strongly agree)

7. SC can invest time and money for carrying out these changes?

- On a scale of 1 - 5 (Strongly disagree to Strongly agree)

8. Do you believe that your department needs any improvements to the way things are done?

- $\mathrm{Yes} / \mathrm{No}$

- Open text box to describe one improvement the participant would like to see implemented.

9. How ready are you for changing the way you or your department does things?

- On a scale of 1 - 5 (Not at all ready to Extremely ready)

10. How influential are you in making change happen in your department?

- On a scale of 1 - 5 (Least influential to Most influential) 